\title{
Pelatihan Keterampilan Komunikasi Interpersonal dalam Membantu Permasalahan Santri di Pondok Pesantren Assalafi Miftakhul Huda Kabupaten Grobogan
}

\author{
Afriyadi Sofyan ${ }^{*}{ }^{1}$, Awalya ${ }^{1}$, Eko Nusantoro ${ }^{1}$, Dian Purbo Utomo ${ }^{1}$ \\ ${ }^{1}$ Jurusan Bimbingan dan Konseling, Universitas Negeri Semarang, Indonesia
}

\section{Article Info \\ Article history: \\ Keyword: \\ First keyword \\ Second keyword \\ Third keyword \\ Fourth keyword \\ Fifth keyword}

Received Oct $19^{\text {th }}, 2020$

Revised Oct $21^{\text {th }}, 2020$

Accepted Nov $14^{\text {th }}, 2020$

Published Nov $30^{\text {th }}, 2020$

\section{Corresponding Author:}

Afriyadi Sofyan,

$\equiv$ afriyadisofyan@mail.unnes.ac.id

\begin{abstract}
Students at the Islamic boarding school for 24 hours and have limited interactions in the boarding school environment are very risky to experience various personal, social and learning problems. Interpersonal Communication Skills Training at the Assalafi Miftakhul Huda Islamic Boarding School in Grobogan Regency provides training to caregivers (senior santri) who will serve as peer guidance. Caregivers are trained to be ready listeners and good friends to help with problems related to other students. Active listening techniques are a specific skill that is trained by caregivers in helping students. Training activities were carried out using lecture and simulation methods on September 13, 2020. The training participants were 50 male and female caregivers. The participants seemed very enthusiastic during the activity. The results of the instrument analysis show that the participants reported the content of the material and the suitability of the written material and the presentation that the team did was the best point in this service activity. On the other hand, the participants stated that the training was too short and felt that they had not had the opportunity to practice. This is a recommendation for the implementation of further community service and needs to be done in a programmed and more intensive manner.
\end{abstract}

(C) 2020 The Authors. Published by IICET

This is an open access article under the CC BY-NC-SA license

(https://creativecommons.org/licenses/by-nc-sa/4.0

\section{Pendahuluan}

Penyelenggaraan lembaga pendidikan berupa pondok pesantren berbentuk asrama (Boarding School) berupa komunitas tersendiri yang di pimpinan oleh kyai atau ulama yang dibantu oleh seorang atau beberapa orang ulama, dan atau para ustadz yang hidup bersama di tengah-tengah para santri dengan masjid atau surau sebagai pusat kegiatan peribadatan keagamaan (Syafe'i, 2017). Kehidupan dalam asrama memiliki kekhasan tersendiri, dimana biasanya gedung-gedung sekolah atau ruang-ruang belajar yang ada akan menjadi pusat kegiatan belajar mengajar, serta pondok-pondok sebagai tempat tinggal santri. Selama 24 jam, dari masa ke masa mereka hidup kolektif antara kyai, ustadz, santri dan para pengasuh pesantren lainnya, sebagai satu keluarga besar (Hayati, 2011). Kehidupan yang demikian dipandang menjadi keunggulan dan karakteristik tersendiri sebagai upaya dalam rangka mewujudkan pendidikan yang intensif guna menanamkan nilai-nilai agama yang kuat 
atau karakter serta cara pandangan kehidupan bermakna tersendiri bagi para peserta didiknya (santri). (Syafe'i, (2017)menemukan banyak penelitian yang telah dilakukan berkenaan dengan pondok pesantren dan pendidikan karakter, beberapa diantaranya (Aulia \& Samino, 2015; Faiqoh \& Mahfudh, 2015; Kurniawan, 2016; Makmun, 2014; Nuryana, 2013; Rodliyah, 2014; Subekti, 2015; Sulaiman, 2013; Ubaidillah, 2016; Zuhriy, 2011).

Pendidikan dengan menggunakan bentuk asrama berupa pondok pesantren bukan tanpa kendala, hambatan dan tantangan. Sebagai lembaga pendidikan nonformal, pendidikan di pondok pesantren memiliki problematika tersendiri dibanding dengan pendidikan formal. Herawati \& Mahyuzar, (2017) menemukan bahwa hambatan yang dihadapi pendidik (ustadz) dalam mencapai keberhasilan pembelajaran adalah adanya salah tafsir dari apa yang disampaikan oleh ustadz sehingga terkadang terjadi kesalahpahaman dan kurangnya respon santri terhadap nasehat-nasehat yang diberikan oleh ustadz. Selanjutnya dijelaskan bahwa ketika ustadz memberikan nasehat kepada santri, tidak jarang ditemui adanya santri yang kurang merespon dengan baik sehingga tidak ada perubahan dari santri itu sendiri. dibutuhkan pemberian nasihat secara berulang-ulang sehingga mampu merubah sikap santri.

Menurut Luthfiyatin, (2007)interaksi masyarakat tutur pesantren (kiai, santri, guru (ustadz/ustadzah), pengurus pondok dan lain-lain) selalu dilandasi oleh norma-norma pesantren. Selanjutnya ia menemukan bahwa pola komunikasi santri terhadap ustadzah maupun pengurus dipengaruhi oleh konteks sosial dan konteks situasi serta perpaduan budaya pesantren dan Jawa komunikasi seorang santri dengan orang yang mempunyai status sosial lebih tinggi, mereka menerapkan sikap wedi (takut), isin (malu), dan sungkan. Tentunya interaksi semacam ini memiliki kelebihan dan kekurangan sendiri. Sebagaimana disampaikan Sanjaya (2016) bahwa keberhasilan pendidik (guru) dalam menyampaikan materi sangat tergantung dengan kelancaran interaksi antara guru dan siswanya. Ketidaklancaran komunikasi dapat membawa akibat pesan yang disampaikan tidak dapat diterima dengan baik atau bahkan bisa tidak diterima sama sekali.

Setiawan et al., (2015) juga mengungkap beberapa fenomena pada sebuah pondok pesantren, diantaranya yaitu: Pertama, setiap santri pada awalnya merasa tidak betah tinggal di Pondok Pesantren hal ini biasanya terjadi hingga tiga sampai enam bulan, dalam masa ini mereka juga menjalani proses penyesuaian melalui peniruan dan pembelajaran dengan dewan asatidz. Kedua, hambatan utama santri dari luar daerah dalam beradaptasi adalah perbedaaan bahasa, karena dalam kegiatan harian dan pembelajaran, warga pesantren menggunakan bahasa daerah setempat; dan yang ketiga, bentuk kenakalan dikategorikan pada pelanggaran ringan dan berat seperti mencuri, gasab, berkelahi, kabur, bolos, merokok dan berambut gondrong.

Berdasarkan hasil wawancara awal yang telah dilakukan pada bulan Februari 2020 terhadap pengelola pondok, telah ditemukan fakta bahwa pengasuh para santi yaitu santri senior yang ditunjuk oleh pengelola PP Assalafi Miftakhul Huda yang usianya kurang lebih tidak jauh berbeda atau hampir dapat dikatakan sebaya dengan santri, dapat dikatakan bahwa pengasuh belum sepenuhnya memiliki keterampilan komunikasi interpersonal yang optimal guna membantu santri asuhnya. Hal ini ditunjukkan dengan cara merespon yang kurang tepat ketika ada santri lain atau junior yang menceritakan masalahnya. Mestinya diharapkan pengasuh mampu memiliki keterampilan komunikasi interpersonal yang baik karena hal ini berguna dalam membantu serta memecahkan persoalan para santri junior didalam mereka menyesuaikan diri dan belajar di lingkungan baru yaitu pesantren. Hal tersebut di istilahkan dengan bimbingan teman sebaya (BTS). Rohayati, (2011) membuktikan bahwa program bimbingan teman sebaya secara efektif meningkatkan percaya diri siswa, kemudian Aminudin, (2012) juga membuktikan bahwa bimbingan teman sebaya untuk siswa terbukti efektif dalam upaya meningkatkan kemampuan komunikasi interpersonal siswa pada aspek percaya, sikap suportif dan sikap terbuka.

Berdasar problema, pemikiran dan temuan diatas perlu kiranya untuk melakukan upaya meningkatkan keterampilan komunikasi interpersonal santri khususnya santri senior agar tercipta suasana kehidupuan pondok yang kondusif, saling support dan mendukung situasi belajar yang maksimal sehingga tujuan pendidikan pondok pesantren untuk melahirkan generasi yang berkarakter dapat tercapai. Upaya yang dilakukan tersebut kiranya juga seiring sejalan dengan upaya mewujudkan 
visi dan misi Universitas Negeri Semarang (UNNES). Sebagai Universitas yang mendedikasikan diri sebagai Universitas berwawasan konservasi dan berwawasan Internasional serta sebagai rumah ilmu yang tentunya diharapkan menjadi pengembang peradaban. Peran, dukungan dan kontribusi serta saling bersinergi perlu terus dijalin dan dikembangkan antar lembaga pendidikan. Pada akhirnya diharapkan cita-cita bersama sebagai sebuah negara yaitu menciptakan sumberdaya manusia yang unggul dapat tercapai

Universitas Negeri Semarang (UNNES) mempunyai visi menjadi Universitas Berwawasan Konservasi Bereputasi Internasional. Untuk mewujudkan visi tersebut salah satu misi UNNES adalah mengembangkan, menciptakan, dan/atau menyebarluaskan ilmu pengetahuan, teknologi, seni, dan olahraga, yang bermakna dan bermanfaat. UNNES memiliki tanggung jawab dan peran strategis untuk meningkatkan mutu pendidikan dan kualitas pendidik di Indonesia. Peran yang dapat dilakukan adalah bersinergi dengan lembaga pendidikan mitra melalui kerjasama dengan bentuk tri dharma perguruan tinggi yaitu pengabdian kepada masyarakat.

Pelatihan Keterampilan Komunikasi Interpersonal dalam Membantu Permasalahan Santri di Pondok Pesantren Assalafi Miftakhul Huda Kabupaten Grobogan dimaksudkan memberikan pelatihan kepada pengasuh (santri senior) yang akan dijadikan atau berperan sebagai pendamping bimbingan teman sebaya (BTS). Dalam kegiatan bimbingan teman sebaya, beberapa santri yang memenuhi kriteria tertentu menjadi calon teman sebaya diberi pelatihan agar siap menjadi pendengar dan sahabat yang baik untuk membantu permasalahan yang dihadapi santri-santri lainnya. Teman yang baik dimaksud adalah teman yang selalu melihat potensi positif / kekuatan dalam diri teman sebayanya.

Untuk menjadi pendengar dan sahabat yang baik mensyaratkan keterampilan komunikasi interpersonal yang memadai. Cangara, (2012) menyatakan bahwa komunikasi interpersonal memiliki peranan penting dalam hubungan antar individu, menghindari dan mengatasi konflik pribadi, mengurangi ketidakpastian, berbagi pengetahuan dan pengalaman dengan orang lain, mengendalikan perilaku, memberi motivasi, sebagai pernyataan emosi, dan memberikan suatu informasi. Dengan berbagai kajian dan pertimbangan diatas maka tim pengabdian merumuskan solusi yang digambarkan dalam kerangka berikut:

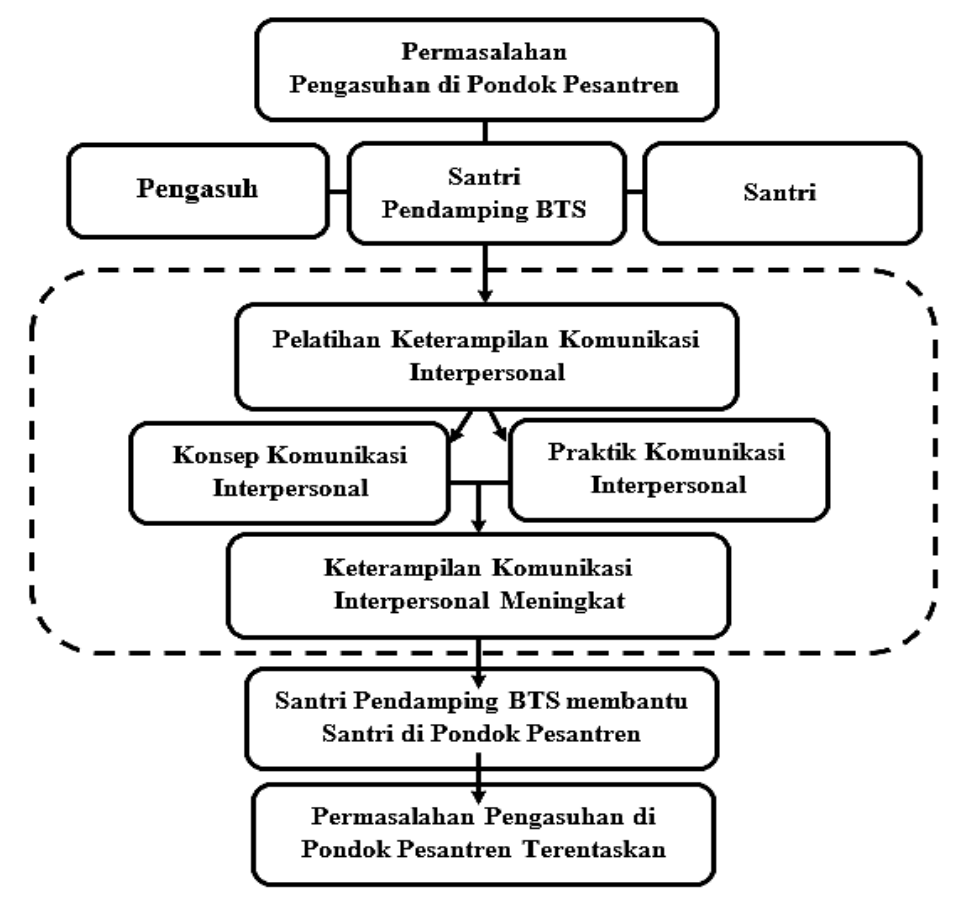

Gambar 1. Kerangka Solusi Permasalahan 


\section{Metode}

Metode pelatihan keterampilan komunikasi interpersonal dilaksanakan dengan metode ceramah, demonstrasi dan simulasi. Metode ceramah digunakan untuk memberikan konsep dasar tentang keterampilan komunikasi interpersonal dan juga mengingat jumlah peserta sebanyak 50 orang peserta. Merujuk pada hasil penelitian Guspita, (2019) ia membuktikan bahwa metode ceramah akan sangat efektif digunakan pada sasaran yang berjumlah lebih dari 15 orang. Hal itu juga sesuai pendapat (Notoatmodjo, 2010); (Iqbal, (2012) yang menyatakan bahwa metode ceramah sering digunakan dan dapat diterima di berbagai sasaran yang banyak dan berbagai kalangan baik pada individu berpendidikan rendah hingga berpendidikan rendah. Selanjutnya guna memberikan pengalaman dan pembelajaran secara nyata dalam sebuah praktik komunikasi interpersonal dan active listening yang ditunjukkan kepada para peserta maka digunakan pembelajaran modeling dengan metode demonstrasi dan simulasi. Metode demonstrasi menjadi pilihan karena telah terbukti efektif dalam pembelajaran sebagaimana diuji oleh Firmansyah et al., (2018); Situmorang \& Situmorang, (2013).

Pengabdian ini akan secara khusus melatihkan 2 aspek yakni konsep komunikasi interpersonal dan praktik komunikasi interpersonal untuk membantu pengasuh Pondok Pesantren Assalafi Miftakhul Huda Kabupaten Grobogan.

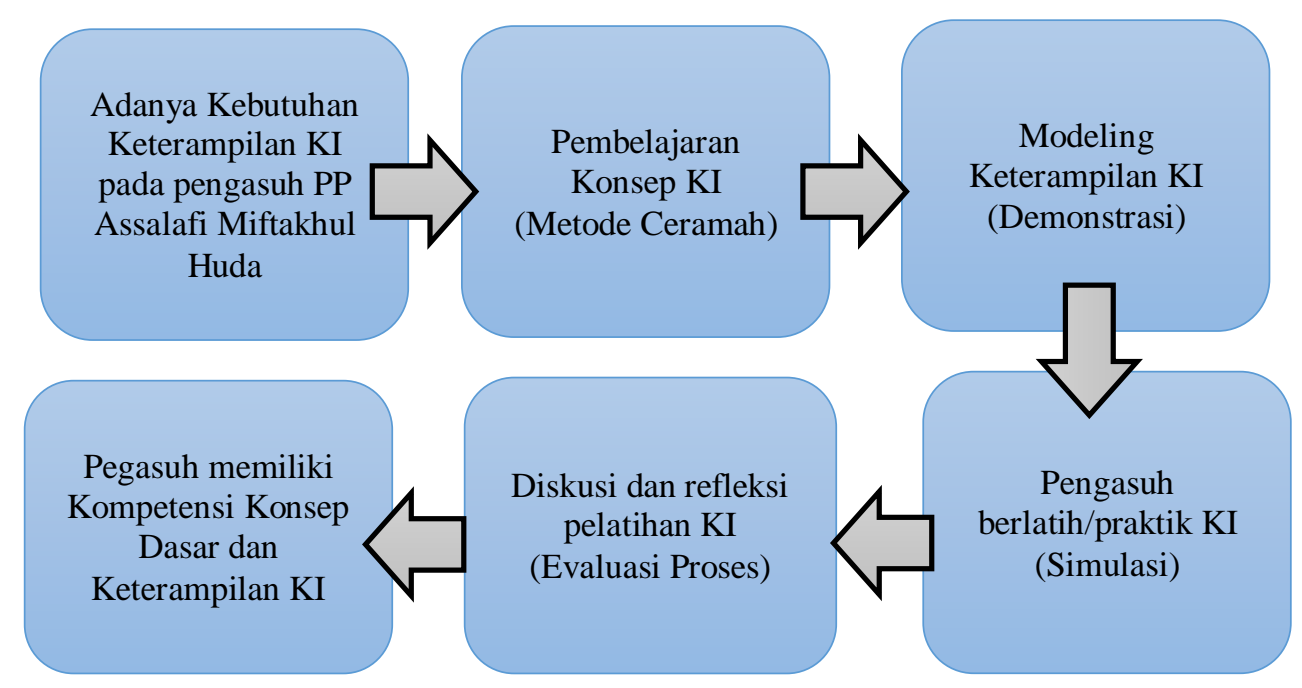

Gambar 2. Metode Pelatihan

Pendekatan/Model yang akan dilaksanakan dalam pengabdian ini berfokus pada capaian kompetensi pengasuh dengan menguasai konsep dasar dan keterampilan komunikasi interpersonal. Kedua aspek ini merupakan kompetensi yang penting yang harus dimiliki oleh pengasuh PP dan pendamping BTS karena dapat membantu pelayanan santri di pondok agar lebih optimal. Melalui implementasi Keterampilan Komunikasi Interpersonal, pengasuh PP dan santri pendamping BTS memiliki kompetensi: Pengantar Komunikasi; Dasar-Dasar Komunikasi Interpersonal; Memahami Komunikasi Verbal; memahami komunikasi nonverbal; active listening dalam upaya perbantuan (konseling) sebaya.

\section{Hasil dan Pembahasan}

Pelaksanaan Pelatihan Keterampilan Komunikasi Interpersonal dalam Membantu Permasalahan Santri di Pondok Pesantren Assalafi Miftakhul Huda Kabupaten Grobogan di tengah situasi pandemi Covid-19 mengahadapi tantangan dan hambatan tersendiri. Sesuai dengan hasil koordinasi rencana kegiatan pengabdian berhasil dilaksanakan dengan urutan atau tahapan berikut:

\section{Perizinan internal lembaga}

Kegiatan pelatihan ini diselenggarakan dengan melibatkan antar dua lembaga yaitu Fakultas Ilmu Pendidikan Universitas Negeri Semarang dan Pondok Pesantren Assalafi Miftakhul Huda Kabupaten Grobogan, dengan demikian aspek legalitas yang teradministrasikan perlu oleh dipenuhi. Tim pengabdi terlebih dahulu melakukan perizinan pada internal lembaga, dalam hal ini pengasuh pondok pesantren dan juga lembaga pengabdi Fakultas Ilmu Pendidikan. Surat izin serta 
surat tugas melakukan pengabdian digunakan sebagai dasar hukum dan legalitas tim pengabdi untuk melaksanakan kegiatan pelatihan dimaksud.

2. Perizinan dan koordinasi dengan Pengasuh Ponpes Assalafi Miftakhul Huda

Tim pengabdi melakukan perizinan dan koordinasi dengan Fakultas Ilmu Pendidikan dan Pengasuh Ponpes Assalafi Miftakhul Huda untuk melakukan kegiatan pengabdian. Pada tahap ini tim pengabdi bersama dengan Pengasuh Ponpes Assalafi Miftakhul Huda mengkoordinasikan waktu pelaksanaan dan rancangan kegiatan pengabdian yang akan diberikan. Pada tahap ini pula dilakukan identifikasi terhadap pengasuh (santri senior) yang diproyeksikan akan menjadi tutor teman sebaya yang kemudian nantinya menjadi peserta kegiatan pelatihan. Akhirnya, sebanyak 50 santri yang berperan sebagai ketua kamar putra dan ketua serta wakil ketua kamar putri menjadi peserta kegiatan pengabdian.

3. Pelaksanaan Kegiatan Pelatihan

Kegiatan pelatihan dilakukan selama 1 hari, berlangsung pada hari Minggu, 13 September 2020 bertempat di Pondok Pesantren Assalafi Miftahul Huda J1. Kauman Nomor 10A Ngroto, Gubug, Kabupaten Grobogan, Jawa Tengah. Adapun tahapan Pelaksanaan pelatihan sebagai berikut:

- Pelatihan diawali dengan perkenalan para tim pengabdian dan dilanjutkan maksud dan tujuan kegiatan pelatihan. Hal ini dilakukan dengan tujuan agar peserta memahami dan dekat dengan tim pengabdian dan memahami apa maksud kegiatan dilaksanakan hingga kemampuan apa yang bias mereka miliki setelah kegiatan nantinya dilaksanakan.

- Sebelum dilanjutkan pada kegiatan pelatihan tim pengabdian mengajak para peserta untuk melakukan games bersama, dengan suasana dapat menjadi cair, hangat dan akrab antar sesama peserta dan tim pengabdian. Dalam kegiatan games para peserta tampak antusias dan tertawa lepas karena ada beberapa rekan atau bahkan dirinya sendiri melakukan hal yang berbeda dengan temannya. Kegiatan dilanjutkan dengan melakukan diskusi untuk mengidentifikasi tingkat pemahaman awal dan permasalahan peserta sebelum diberikan pelatihan.

- Kegiatan inti atau pelatihan berlangsung melalui metode ceramah dan tanya jawab serta modeling terkait ketrampilan komunikasi interpersonal. secara terstruktur tim menyampaikan materi pelatihan dimulai dari konsep dasar keterampilan komunikasi, bentuk komunikasi, hambatan komunikasi hingga membahas active listening (materi/modul terlampir). Dalam penyampaikan materi sesekali peserta diberikan kesempatan untuk bertanya jika ada beberapa hal yang kurang dipahami. Setelah materi disampaikan, kegiatan di lanjutkan dengan pemberian contoh dalam komunikasi efektif interpersonal serta keterampilan active listening sebagai tutor sebaya. Tim menampilkan simulasi sebagai upaya modeling bagi para peserta. Dalam kegiatan ini dilaksanakan secara interaktif. Beberapa kali peserta memberikan balikan dan respon berupa pertanyaan dari simulasi yang dilakukan. Hingga waktu pelatihan yang tentukan berakhir kegiatan berjalan secara lancar dan dalam suasana yang hangat dan terasa suasana pembelajaran yang aktif.

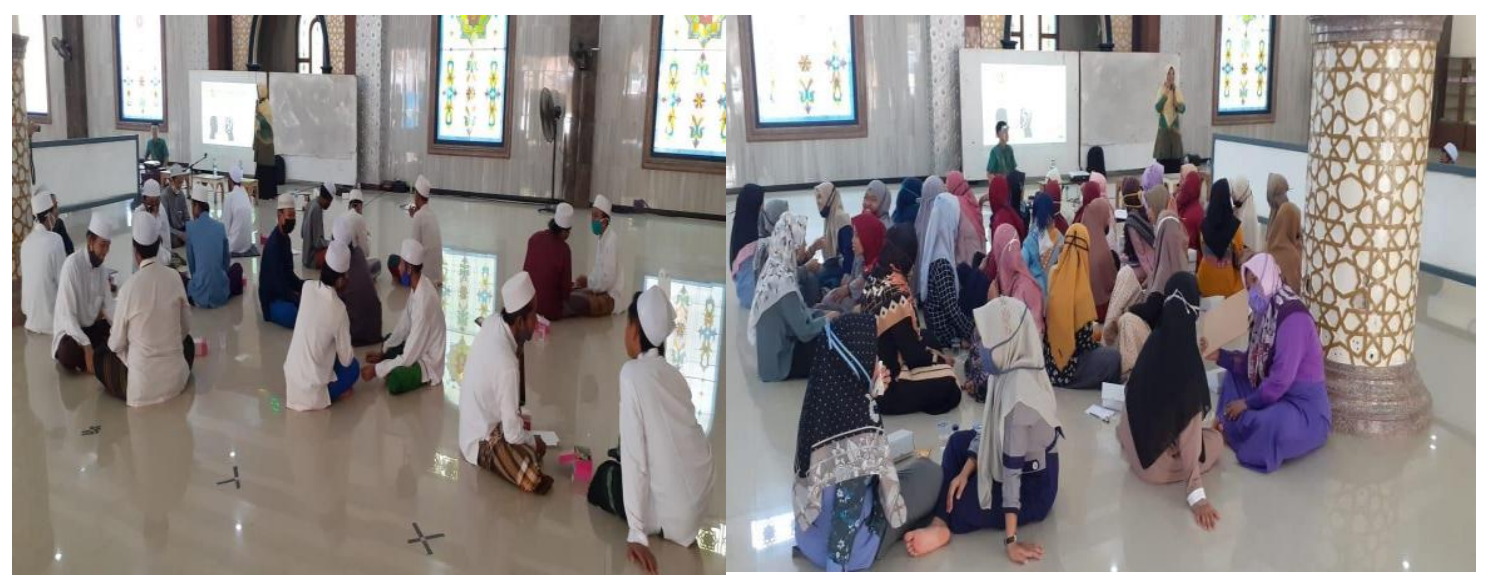

Gambar 2. Dokumentasi Pelaksanaan Kegiatan 
- Setelah kegiatan pelatihan dilaksanakan, kemudian peserta diminta untuk mengisi lembar form evaluasi. Evaluasi hasil yang dilakukan mencakup materi, metode dan fasilitas pendukung dalam kegiatan (Form terlampir). Form evaluasi skala penilaian 1 hingga 4. Dimana pemaknaannya dijelaskan sebagai berikut :

- Skala penilaian 1: Tidak memadai / tidak tepat

- Skala penilaian 2: Kurang memadai / kurang tepat

- Skala penilaian 3: Cukup memadai / cukup tepat

- Skala penilaian 4: Memadai / tepat

Dari hasil analisis terhadap lembar evaluasi yang telah diisi peserta pelatihan didapatkan skor rata-rata 75,62. Nilai tersebut jika dilihat dalam kriteria yang ditetapkan sebagai berikut:

Tabel 1. Kriteria Pelaksanaan Pengabdian

\begin{tabular}{cl}
\hline Skor & Kriteria \\
\hline $\mathbf{8 1 - 1 0 0}$ & Sangat Baik \\
$\mathbf{6 1 - 8 0}$ & Baik \\
$\mathbf{4 1 - 6 0}$ & Cukup \\
$\mathbf{2 1 - 4 9}$ & Kurang \\
$\mathbf{0 - 2 0}$ & Sangat Kurang \\
\hline
\end{tabular}

Mengacu pada table 1 di atas dapat diketahui bahwa skor evaluasi pelaksanaan pengabdian berada dalam kategori baik. Selanjutnya mengacu pada hasil analisis item yang dilakukan menggunakan pemodelan rasch degan bantuan aplikasi Winstep versi 4.4 .5 dapat dilihat dalam table berikut:

Tabel 2. Hasil olah pemodelan Rasch

\begin{tabular}{cll}
\hline Logit Measure & Out MNSQ & No Item \\
\hline $\mathbf{1 . 1 2}$ & 1.74 & $\mathrm{I}$ \\
$\mathbf{. 9 3}$ & 1.15 & $\mathrm{I} 8$ \\
$\mathbf{4 8}$ & 1.50 & $\mathrm{I} 4$ \\
$\mathbf{4 8}$ & .58 & $\mathrm{I} 7$ \\
$\mathbf{. 4 8}$ & .38 & $\mathrm{I} 12$ \\
$\mathbf{. 4 2}$ & .66 & $\mathrm{I} 10$ \\
$\mathbf{. 0 9}$ & .89 & $\mathrm{I} 11$ \\
$\mathbf{- . 1 8}$ & .95 & $\mathrm{I} 13$ \\
$\mathbf{- . 4 5}$ & 1.08 & $\mathrm{I} 5$ \\
$\mathbf{- . 4 5}$ & 1.19 & $\mathrm{I} 6$ \\
$\mathbf{- . 8 0}$ & .72 & $\mathrm{I} 2$ \\
$\mathbf{- . 8 0}$ & 1.36 & $\mathrm{I} 3$ \\
$\mathbf{- 1 . 3 3}$ & .69 & $\mathrm{I} 1$ \\
\hline
\end{tabular}

Tampak dari table tersebut bahwa dari 13 item yang disediakan, no item 9 dan 8 menjadi item yang sangat sulit untuk disetujui/diterima oleh peserta pelatihan. Adapun pernyataan item tersebut adalah no 9 yaitu "waktu yang disediakan" dan no 8 yaitu "kesempatan berlatih". Sedangkan item yang sangat mudah diterima/disetujui oleh peserta adalah nomor 1 dan nomor 3. Dimana pernyataan dimaksud nomor 1 yaitu "cakupan isi materi" dan nomor 3 yaitu "kesesuaian materi tulis dan penyajian".

Kegiatan pelatihan keterampilan komunikasi interpersonal didasari dari kenyataan bahwa pengasuh para santi yaitu santri senior yang ditunjuk oleh pengelola PP Assalafi Miftakhul Huda yang usianya kurang lebih tidak jauh berbeda atau hampir dapat dikatakan sebaya dengan santri, dapat dikatakan bahwa pengasuh belum sepenuhnya memiliki keterampilan komunikasi interpersonal yang optimal guna membantu santri asuhnya. Hal ini ditunjukkan dengan cara merespon yang kurang tepat ketika ada santri lain atau junior yang menceritakan masalahnya. Dengan diselenggarakannya kegiatan pelatihan ini diharapkan pengasuh mampu memiliki keterampilan komunikasi interpersonal yang baik karena hal ini berguna dalam membantu serta memecahkan persoalan para santri junior didalam mereka menyesuaikan diri dan belajar di lingkungan baru yaitu pesantren, hal tersebut di istilahkan dengan bimbingan teman sebaya (BTS). 
Pelaksanaan pengabdian ini tentu saja tidak kemudian akan memberikan dampak yang langsung dengan terentaskannya masalah yang terjadi pada santri di pondok pesantren. Namun upaya kegiatan pelatihan keterampilan komunikasi interpersonal ini menjadi dasar dan modal bagi pengasuh untuk dapat membantu rekan santri lainya terutama santri junior atau adik kelas mereka. Upaya ini sangat diperlukan mengingat santri junior terutama mereka yang masih baru tinggal di pondok pesantren masih dalam masa penyesuaian lingkungan baru. Sebagaimana disampaikan oleh Setiawan et al., (2015) yang mengungkap beberapa fenomena pada sebuah pondok pesantren, diantaranya yaitu: Pertama, setiap santri pada awalnya merasa tidak betah tinggal di Pondok Pesantren hal ini biasanya terjadi hingga tiga sampai enam bulan, dalam masa ini mereka juga menjalani proses penyesuaian melalui peniruan dan pembelajaran dengan dewan asatidz. Kedua, hambatan utama santri dari luar daerah dalam beradaptasi adalah perbedaaan bahasa, karena dalam kegiatan harian dan pembelajaran, warga pesantren menggunakan bahasa daerah setempat; dan yang ketiga, bentuk kenakalan dikategorikan pada pelanggaran ringan dan berat seperti mencuri, gasab, berkelahi, kabur, bolos, merokok dan berambut gondrong.

Berbagai problema diatas tentunya akan terminimalisir dan bahkan dapat ditangani hingga tuntas jika di upayakan oleh semua pihak, termasuk didalamnya adalah santri yang sudah terlebih dahulu berada di pondok pesantren tersebut. Mereka sudah melalui masa-masa penyesuaian dan pembiasaan di dalam lingkungan pondok. Dengan ikut sertanya para pengasuh (santri senior) dalam kegiatan pelatihan ini yang tampak antusias dalam kegiatandengan ditandai jumlah peserta sejumlah 50 orang yang ini pun dari hasil koordinasi dengan pengurus pondok mengharapkan lebih dari jumlah tersebut karena memang banyak peserta yang ingin mengikutinya. Namun tim pengabdian membatasi untuk jumlah peserta karena pertimbangan akan berdampak pada efektifitas pelaksanaan kegiatan pelatihan. Dikhawatirkan jika terlalu banyak peserta yang hadir sedangkan jumlah tim pengabdian terbatas maka materi pelatihan tidak tersampaikan dengan baik karena tidak kondusifnya kegiatan serta terbatasnya sarana kegiatan.

Melihat evaluasi proses kegiatan, dengan segala keterbatasan tim dan sarana yang ada, sedangkan jumlah peserta sangat banyak, upaya tim kiranya sudah cukup optimal dengan diperolehnya hasil pelaksaanaan dinilai baik oleh peserta kegiatan. Kerjasama antar berbagai pihak terutama Fakultas Ilmu Pendidikan dan pihak Pondok pesantren kiranya sudah sangat maksimal. Namun tentunya masih menjadi semangat dan tekad bersama untuk mewujudkan visi dan misi dari lembaga masing-masing pihak. Kiranya kerjasama yang tertuang dalam MoU kedepan perlu dilanjutkan dan ditingkatkan. Hal ini disadari oleh tim pengabdian setelah melihat hasil evaluasi yang menyatakan bahwa peserta merasa waktu dan kesempatan berlatih bersama tim masih kurang.

Selanjutnya dari evaluasi diketahui juga bahwa peserta menyatakan bahwa cakupan isi materi dan kesesuaian materi tulis dan penyajian yang tim lakukan menjadi point terbaik dalam kegiatan pengabdian ini. Hal tersebut kiranya menjadi gambaran akan kesesuaian apa yang menjadi tujuan dan upaya penyelesaian terhadap permasalahan yang dihadapi atau kebutuhan akan dukungan yang di rasakan oleh pengasuh sudah terjawab atau terbantu dengan pelaksanaan pengabdian ini. Semua itu tentunya tidak lepas dari kerjasama dan kesepemahaman dari semua pihak, baik pelaksana pengabdian, pihak fakultas ilmu pendidikan Universitas Negeri Semarang, serta pihak pengelola pondok pesantren Miftahul Huda. Keberhasilan ini patut menjadi perhatian dan layak mendapatkan apresiasi serta menjadi modal kedepan untuk meningkatkan Kerjasama dalam bentuk yang lebih luas dan berkelanjutan. Visi dan misi Fakultas hingga Universitas Negeri Semarang kiranya dapat diakomodir dalam kegiatan-kegiatan serupa. Peran sebagai pemecah persoalan hingga memberikan dukungan bagi semua pihak dan kalangan terbukti dibutuhkan dan memberikan kontrubusi nyata bagi masyarakat.

Tim pengabdian pada akhirnya menyadari bahwa kegiatan ini adalah bagian kecil dari sebuah upaya yang dapat dilakukan dengan segala keterbatasan dan kekurangan yang ada. Masih banyak hal lain yang perlu dilakukan dan melibatkan berbagai pihak. Kapasitas dan kompetensi dari tim pengabdian juga menjadi hal yang tidak bisa diabaikan, tim pengabdian sangat menyadari bahwa kegiatan ini juga mampu menjadi sarana mengasah dan aktualisasi dari keilmuan serta keterampilan yang dimiliki oleh tim pengabdian. Untuk itu, tim sangat menyarankan bagi berbagai pihak yang ingin terlibat ataupun melakukan kegiatan serupa, kedepan perlu upaya berkesinambungan dari kegiatan pengabdian ini. Dengan harapan persoalan yang harus diselesaikan juga akan secara simultan dan komprehensif dapat diatasi.

\section{Simpulan}

Berdasarkan pelaksanaan kegiatan pelatihan keterampilan komunikasi interpersonal khususnya terkait teknik active listening dapat disimpulkan bahwa kegiatan pelatihan terselenggara dengan baik dan 
para peserta menyatakan sangat memerlukan pelatihan ini serta mengharapkan untuk diselenggarakan kegiatan serupa atau bagian dari kelanjutan kegiatan pengabdian yang telah terlaksana di waktu mendatang.

Diharapkan kepada pihak fakultas ilmu Pendidikan Universitas Negeri Semarang dan pondok pesantren dapat memfasilitasi kegiatan lanjutan di waktu mendatang. Pihak Pondok pesantren diharapkan untuk terus memberikan dukungan sarana dan prasarana kepada para pengasuh demi terciptanya lingkungan Pendidikan yang kondusif. Para pengasuh (santri senior) disarankan untuk terus berlatih keterampilan komunikasi interpersonal dan khususnya teknik active listening secara mandiri maupun kelompok dalam upaya mengasah kemampuan keterampilan interpersonal guna membantu santri.

\section{Acknowledgements}

Tim pengabdian sangat bersyukur dan selanjutnya juga berterimakasih kepada pihak Fakults Ilmu Pendidikan Universitas Negeri Semarang (FIP-UNNES) yang telah mendukung penuh baik secara material mupun nonmaterial, dibuktikan dengan diberikannya bantuan pendanaan penuh melalui Daftar Isian Pelaksanaan Anggaran (DIPA) Fakultas Tahun 2020 Nomor: 3.15.5/UN37/PPK.4.1/2020 Tanggal: 15 Mei 2020 Sesuai Surat Perjanjian Penugasan Pelaksanaan Program Pengabdian DIPA Fakultas Tahun 2020 Nomor: 86.11.5/UN37/PPK.4.1/2020 Tanggal 11 Mei 2020. Hal ini menunjukkan komitmen FIP UNNES untuk menjadi rumah ilmu dan pengembang peradaban yang sejalan dengan visi dan misi yang selama ini di gaungkan. Tim pengabdian juga sangat berterima kasih dan memberikan apresiasi kepada pihak Pondok Pesantren Assalafi Miftakhul Huda Kabupaten Grobogan yang telah berkenan untuk bekerjasama dan bersinergi untuk melakukan hal yang positif dan konkret sebagai upaya nyata menjunjung tinggi marwah sebagai pembaga pendidikan dan upaya untuk terus mewujudkan pendidikan yang berkualitas serta inovasi mengatasi problema dalam penyelenggaraan Pendidikan.

\section{Referensi}

Aminudin, D. (2012). Efektivitas Bimbingan Teman Sebaya dalam Meningkatkan Kemampuan Komunikasi Interpersonal Siswa. Universitas pendidikan indonesia.

Cangara, H. (2012). Pengantar Ilmu Komunikasi. Raja Grafindo Persada.

Firmansyah, F., Firmansyah, D., Cibaduyut, S. B. U., \& Siliwangi, I. (2018). Penerapan Metode Demonstrasi Berbasis Media Cerita Lucu Bergambar dalam Pembelajaran Menulis Teks Anekdot pada Siswa. Parole (Jurnal Pendidikan Bahasa Dan Sastra Indonesia), 1(4), 585-590.

Guspita, H. (2019). Efektivitas Promosi Kesehatan menggunakan Metode Ceramah tentang HIV/AIDS terhadap Pengetahuan dan Sikap Remaja di SMK Tritech Informatika dan SMK Namira Tech Nusantara Medan tahun 2016. Jurnal Ilman: Jurnal Ilmu Manajemen, 5(1).

Hayati, F. (2011). Pesantren: Suatu Alternatif Model Lembaga Pendidikan Kader Bangsa. Mimbar: Jurnal Sosial Dan Pembangunan, 27(2), 157-163.

Herawati, C. E., \& Mahyuzar, M. (2017). Komunikasi Interpersonal Ustadz Dengan Santri Terhadap Keberhasilan Program Tahfizhul Qur'an (Studi Pada Pesantren Modern Ulumul Qur'an Pagar Air Aceh Besar). Jurnal Ilmiah Mahasiswa Fakultas Ilmu Sosial \& Ilmu Politik, 2(4).

Iqbal, M. W. (2012). Ilmu kesehatan masyarakat konsep dan aplikasi dalam kebidanan. Jakarta: Salemba Medika.

Luthfiyatin, I. (2007). Kesantunan Imperatif dalam Interaksi Antarsantri Putri Pondok Pesantren Sunan Drajat Banjaranyar Paciran Lamongan Jawa Timur. UNIVERSITAS AIRLANGGA.

Notoatmodjo, S. (2010). Promosi Kesehatan Teori dan Aplikasi. Rineka Cipta.

Rohayati, I. (2011). Program bimbingan teman sebaya untuk meningkatkan percaya diri siswa. Jurnal UPI, Edisi Khusus,(1).

Sanjaya, W. (2016). Strategi pembelajaran berorientasi standar proses pendidikan (Edisi $1 \mathrm{Ce}$ ). Kencana Prenada Media.

Setiawan, Y., Kosasih, A., \& Komariah, S. (2015). Pola adaptasi sosial budaya kehidupan santri pondok pesantren nurul barokah. SOSIETAS, 5(1).

Situmorang, H., \& Situmorang, M. (2013). Efektivitas Metode Demonstrasi Dalam Meningkatkan Hasil Belajar Siswa Sekolah Menengah Kejuruan Pada Pengajaran Sistem Koloid. Jurnal Penelitian Bidang Pendidikan, 19(1), 28-36.

Syafe'i, I. (2017). Pondok pesantren: Lembaga pendidikan pembentukan karakter. Al-Tadzkiyyah: Jurnal Pendidikan Islam, 8(1), 61-82. 